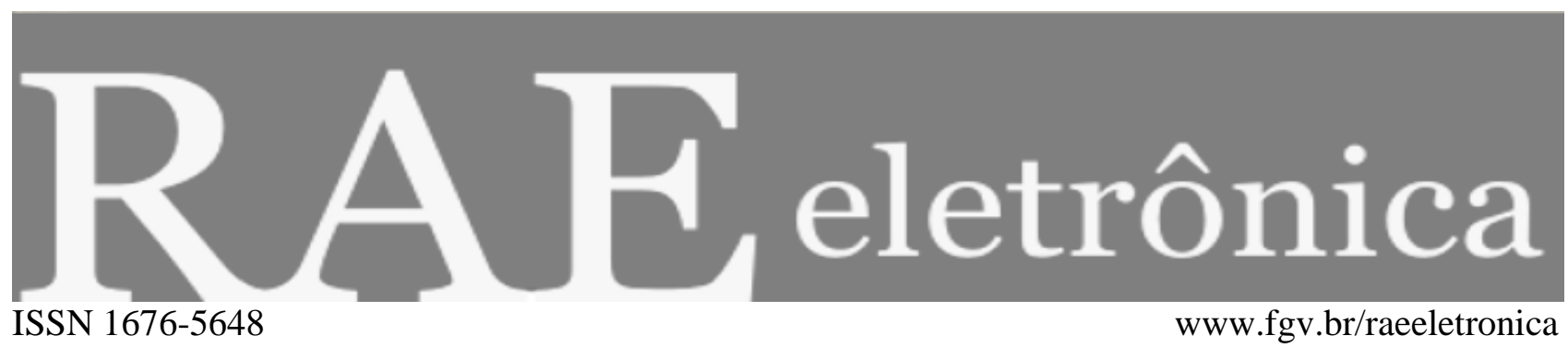

\title{
RESENHA
}

\section{DISCUTINDO A EXPATRIAÇÃO DE EXECUTIVOS}

\section{Anderson Queiroz Lemos}

Mestrando em Administração de Empresas pelo Centro de Estudos Sociais Aplicados, Universidade Estadual do Ceará, CE - Brasil

andersonqadm@gmail.com

CCopyright 2009 FGV-EAESP/RAE-eletrônica. Todos os direitos reservados. Permitida a citação parcial, desde que identificada a fonte. Proibida a reprodução total. Em caso de dúvidas, consulte a Redação: raeredacao@fgv.br; 55 (11) 3799-7898.

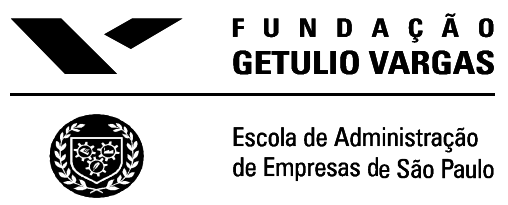




\section{DISCUTINDO A EXPATRIAÇÃO DE EXECUTIVOS}

\section{EXPATRIAÇÃO DE EXECUTIVOS}

De Leni Hidalgo Nunes, Isabella F. Gouveia Vasconcelos, Jacques Jaussaud

São Paulo: Thomsom Learning, 2008. 134p.

Para promover vantagem competitiva, organizações executam uma prática sofisticada, complexa e onerosa de geração e difusão de conhecimento: a expatriação de executivos. Nesse contexto, fronteira, como sinônimo de regulação e controle, perde o sentido a luz da obra apresentada por Nunes, Vasconcelos e Jaussaud (2008).

A aproximação dos autores com as ciências sociais e humanas, com mestrado e doutorado nestas áreas, desprende atenção especial na obra ao que concerne desenvolvimento humano e social. A análise do processo de expatriação permite a inserção da leitura em cursos acadêmicos voltados a gestão de pessoas. Também é apresentado o tema da economia informacional, tendo como base a geração de riqueza por meio da disseminação da informação, que ganha espaço à medida que a internacionalização das organizações deixa de ser fenômeno e se torna variável influenciadora do processo de crescimento das empresas.

Destaca-se na obra o viés do estudo comportamental, teoria dos recursos da firma, teoria das organizações, teoria behaviorista, o problema do risco moral e das informações assimétricas. Frente à complexidade da expatriação de executivos está a necessidade do desenvolvimento e manutenção destes profissionais, vistos como ativos intangíveis e cada vez mais procurados pelas grandes corporações.

Os autores apresentam a preparação e a necessidade de qualificação profissional como fonte geradora de vantagem competitiva, enfatizando a gestão de pessoas no sucesso do processo de expatriação. Este investimento é posto a prova no intercâmbio entre executivos. Os autores trazem os aspectos culturais dos países de destino dos executivos expatriados na obra como um dos fatores motivadores dessa prática. Dai a hipótese da difícil replicação da vantagem competitiva em curto prazo. 
São abordadas diversas correntes, inclusive de base teórica francesa. As referências às obras de Michel Crozier, com o aprofundamento na corrente do poder, e de Erhard Friedberg, sobre a teoria do poder, respaldam a densidade da pesquisa. Tais correntes ajudam a explicar de uma maneira sofisticada não só a colonização brasileira, mas novas influências estrangeiras, oriundas das proximidades organizacionais mundiais. É necessário que o leitor esteja atento para perceber as formas, imbricadas no texto, como os autores apresentam as estratégias de proteção e aprendizagem do executivo durante o processo de expatriação.

$\mathrm{Na}$ primeira corrente os autores apresentam diversas teorias e modelos para justificar o intercâmbio profissional como estratégia de desenvolvimento pessoal e organizacional. Contudo, a literatura que trata temas relacionados a negócios demonstra que a eficácia não se obtém seguindo um modelo organizacional sem as devidas adaptações, principalmente em ambientes muito competitivos.

Os autores fazem leves menções ao problema da agência quando retratam o conflito entre cooperação e poder no processo de aprendizagem coletiva. Esse aspecto microeconômico poderia ter sido um pouco mais explorado, uma vez que suas implicações são de interesse direto da teoria das organizações.

A segunda corrente traz considerações 'weberianas' e 'tayloristas', de forma que se retrata bem a preocupação de uma organização capitalista em controlar os grupos que nela se formam e instituir regras, evitando assim, dissipação de energia da empresa com a solução de conflitos.

Por se tratar de cultura, a obra revela a importância da coletividade para o processo de mudança organizacional, avançando de forma que os autores demonstram qual o interesse do expatriado no novo jogo de poder em que ele se inseriu, ou seja: colaboração, cooperação e adaptação. Para tanto, os autores entendem que as organizações que praticam a expatriação precisam de recursos para manter seus executivos; caso contrário, emerge o problema do risco moral.

Os autores adotam abordagem antropológica para demonstrar a organização no contexto cultural, em que cultura é uma interpretação essencialmente semiótica. Demonstra-se que a percepção da realidade pelo individuo é de extrema importância para explicar o surgimento de subculturas nas organizações e como a partir de coalizões os membros organizam suas interações sociais. O que os autores afirmam é que profissionais expatriados podem internalizar a cultura estrangeira, mesmo que superficialmente, de forma a sobreviverem com êxito ao processo da expatriação.

Ao final do livro, apresenta-se um estudo de caso que embasou uma dissertação na França, país dos expatriados na obra. Apresenta-se o ambiente amigável brasileiro como um fator influenciador da adaptação do executivo estrangeiro, havendo uma breve contradição quando se subentende a 
expatriação como via de mão dupla, pois fica claro ao leitor a diferença de potencial entre o poder dos executivos da matriz frente aos da filial. Reflete-se então sobre o 'homem econômico' estrangeiro, como ser exacerbado de racionalidade.

Observou-se na obra a necessidade de se explorarem os efeitos da expatriação no seio familiar, uma vez que a adaptação à cultura do país de destino é considerada como essencial. Contudo, não se pode ignorar que a obra faz parte de uma coleção que debate a administração e serve ao aprofundamento de temas ainda pouco explorados. A leitura da obra é pertinente a administradores e ajuda pesquisadores e professores a entender e explicar o atual cenário mundial no que concernem as disputas por poder organizacional e eventuais processos de xenofobia que possam surgir em organizações multinacionais. 